\title{
Buying Mechanism of Green Products:
}

\author{
Case of a Developing Country
}

\author{
Stella Y. Sahetapy*, Robert M. Noach \\ Business Administration Department \\ State Polytechnic of Kupang \\ Kupang, Indonesia \\ *stella.sahetapy@pnk.ac.id, robert.noach95@gmail.com
}

\begin{abstract}
Green consumerism has been an interesting aspect both for scholars and practitioners due to the growing environmental awareness among consumers globally. The aim of this study was to propose a theoretical explanation of the relationship between green product and purchasing intentions of the product in the context of developing countries. Based on a quantitative experimental study, we exhibited that green product influenced purchasing intention indirectly, but no directly through environmental concern. The present study demonstrated that environmental concern among consumers plays a crucial role in inducing purchasing decision of green products. The theoretical and practical contributions as well as direction of future studies were presented.
\end{abstract}

Keywords-green product, environmental concern, purchase intention, developing country

\section{INTRODUCTION}

The environment is a central part of human ecosystems. Unfortunately, humans with technological advances have disrupted the ecosystem by exploring and exploiting it completely without taking into account its sustainability in the future. Environmental problems such as air and water pollution, ozone depletion and global warming started when human over-consumptions started [1]. This situation encourages environmental activists and all parties who concern about the environment to campaign healthier and more responsible consumption while at the same time paying attention to environmental sustainability [2]. In order to achieve this goal, it is necessary to change conventional production patterns to new environmentally friendly ones. Thus, new products are emerging that are designed to respond to the consumers' desires of friendly environmental products. In general, these types of products are considered to have a relatively low negative impact on the sustainability of the human ecosystem [3].

Green marketing is one of the new marketing strategies that have been implemented in various developed countries [4]. This type of marketing is encouraged to anticipate a shift in global consumption patterns from conventional products to organic products or products that represent environmental concerns. Green marketing can be applied as an effort to motivate consumers to be more concerned about the environment, which can be accomplished by manufacturers in the field of cosmetics, sportswear and various other products [5]. Considering the important role of consumers in either protecting or damaging the environment, green marketing is recommended not only by producers but also by governments and non-for-profit organizations [3]. However, challenges in implementing green marketing include how to alter consumer preferences, to face suspicion toward green marketers and consumers' dislike of green products as well as high investment costs in developing green products compared to conventional products [6].

Previous research on green marketing has been carried out by highlighting various aspects $[1,7,8]$. However, research in this area that investigates the mechanism of the influence of green products on purchase intentions in green products is still limited. Therefore, this study aims to reveal the mechanism especially in developing countries where this type of research has not been frequently conducted. To achieve this goal, the data collection in this study was carried out by experimental methods where the data obtained reflects the responses of the respondents to the stimulation.

\section{LITERATURE REVIEW}

\section{A. Green Marketing, Green Products and Environmental Concern}

Green marketing is often seen as an effort to "green" traditional marketing. That is, green marketing is actually another form of traditional marketing with environmental themes. In other words, green marketing seeks to sell green products to consumers who have environmental concerns [2]. In this case, green marketing is often blamed as marketing activities which is carried out with the ultimate aim of increasing sales solely, not entirely aimed at preserving the environment. This is associated with the increasing competition in the business world as the background of green marketing and green consumerism. As a continuation and green marketing, green consumerism begins with consumers' awareness of their rights to obtain products that are feasible, safe, and products that are environmentally friendly. Therefore, 
it is not uncommon that companies apply environmental campaign as one of their marketing strategies [5].

In general, green products are known as ecological products or environmentally friendly products. According to Albino, et al. [9], green products are designed to minimize the usage of materials that cannot be renewed, and materials that contain chemicals that may harm the environment. Therefore, a green product is a product that is considered safe for humans and the environment, efficient usage for resources, can be recycled, and does not commit cruelty to animals [10]. Environmentally friendly labels is often used by green products to convince consumers about environmental issues, both local and global [11]. It is expected that by using environmentally friendly labels, green products can function as a notification for the community to raise awareness or concern for the environment. Environmental concern is a predictor of positive behavior towards environmentally friendly products and is considered a level of emotional commitment from consumers to various environmental issues [4]. According to Rini, et al. [12], environmental concern is a form of attention which can have positive consequences to the environment.

\section{B. Environmental Concerns and Green Product Purchase \\ Intentions}

Attitude is a set of beliefs regarding a particular object or an action that is implemented with an interest to carry out the action [13]. Interest on one hand is a determination to act according to attitude. For example, interest in buying products that are environmentally friendly is considered as a factor that influences the purchasing behavior of the product. Shah, et al. [14] argues that purchasing intention is a process of studying and analyzing the reasons why consumers buy products in certain places. Thus, marketers learn the reasons consumers have the intention to buy a product. According to Simamora [15], the purchase intention of a product arises because there is a basis of trust in the product accompanied by the ability to buy the product. In addition, the purchase intention of a product can also occur with the influence of other people trusted by potential customers. Purchase intention can also arise if a consumer is interested in various information about the product obtained through advertising, the experience of people who have used it, and the urgent needs of a product.

Consumers' concern for the environment is implemented by choosing green products which are believed to improve the quality of the environment and also the quality of lives [16]. This shows that environmental awareness can be a major factor in the consumer decision making process or in other words there is an influence of environmental concern on purchase intentions on green products [17,18]. Similar study in developing countries found consistent results that environmental awareness has a positive effect on purchase intentions for consumers of green products, for example in Malaysia [19], India [20] and Indonesia [12]. The studies above indicate that the more environmental concerns, the purchase intention of green products will increase. Based on the aforementioned review, we predict that environmental concern mediates the relationship between green product and green product purchase intention.

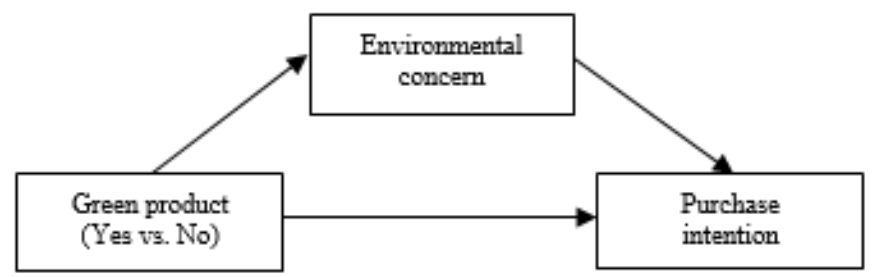

Fig. 1. The mediating role of environmental concern in the link between green product and purchase intention.

\section{METHODS}

\section{A. Samples and Data collection}

This is a quantitative experimental research, where independent variable was manipulated in order to obtain a significant response from the respondents. The respondents in this study were Indonesians who were randomly selected following the convenience sampling procedure. The respondents are adults, willing without coercion to fill out a questionnaire, and do not aware of the hypothesis of this study. These requirements must be met so the answers from respondents are not biased. They were allowed to stop at any time if they feel uncomfortable.

The respondents were divided into 2 groups namely the green group and the non-green group. The green group consisted of respondents who were asked to read leaflets about green bath soap products. It was explained in the leaflet that the soap was made without any chemical substances so that it was not harmful to the environment. Whereas, respondents in the non-green group saw and read leaflets about a conventional (i.e., non-green) soap product. After seeing and reading the leaflet, respondents were asked to fill out a questionnaire regarding environmental concerns and interest in buying the abovementioned soap products as well as filling out demographic data. As a form of gratitude, at the end of the session, the respondents were given souvenirs. Finally, the respondents were debriefed and thanked.

\section{B. Measures}

The questions in the survey were adapted from previous studies on environmental concerns and green products. For environmental concern variables, the measurement scale was adapted from previous studies conducted by Bohlen, et al. [17]. Sample items include, "The increasing destruction of the environment is a serious problem", and "A substantial amount of money should be devoted to environmental protection." The scale for purchasing interest in green products was obtained from research conducted Kim and Chung [21]. The sample item is, "It is likely that I will purchase this organic soap."

Manipulation check questions comprised of a selfdeveloped 2 item-scale. Sample item is, "This product is 
environmentally friendly." All continuous variables were measured using a 7-point Likert scale.

\section{Analysis Technique}

This study aims to investigate the existence of the relationship between variables, it uses path analysis with the help of statistical software such as SPSS and Macro [22]. The stages of the analysis will be divided into initial and further analyses. Initial analysis is carried out to ensure that all measurement scales are valid and reliable, ensuring that the research model meets the assumptions of multivariate statistical analysis. Subsequently, further analysis is basically to test the hypotheses that have been built.

\section{RESULTS}

\section{A. Descriptive Statistics}

The reliability and normality of the continuous variables were examined. Cronbach alpha for continuous variables are demonstrating sufficient level of consistency [23]. All continuous variables were undergone normality testing. Shapiro-Wilk test results indicated that the continuous variables are valued between -1 and 1 , thus all the variables are considered normally distributed [23].

TABLE I. DESCRIPTIVE STATISTICS, CORRELATIONS AND CRONBACH ALPHA

\begin{tabular}{|ll|c|l|c|c|}
\hline \multicolumn{2}{|c|}{ Variable } & $\boldsymbol{\alpha}$ & Mean & SD & Correlation \\
\hline 1. & Environmental concern & .84 & 4.23 & 2.05 & \\
\hline 2. & Purchase intention & .97 & 6.02 & 1.58 & $.21^{* *}$ \\
\hline \multicolumn{6}{|c}{ Correlation is significant at the 0.01 level (2-tailed) }
\end{tabular}

\section{B. Manipulation Check}

The results of an independent sample t-test demonstrated that the respondents who saw the green leaflet consider the product (i.e., soap) is more "green" $(\mathrm{M}=6.19, \mathrm{SD}=1.41)$ than those who saw the non-green leaflet $(\mathrm{M}=5.50, \mathrm{SD}=1.56)$; $\mathrm{t}(164) 2.97, \mathrm{p}<.001)$. This indicated that the green vs. nongreen leaflet managed to stimulate significant responses from respondents.

\section{Hypothesis Testing}

In order to examine the model, green product $\rightarrow$ environmental concern $\rightarrow$ purchasing intention, the data were tested with a mediation analysis [Process Model 4; 22] with 5,000 resamples. Green product as a dichotomous variable was dummy-coded as $1=$ Yes and $0=$ No.

The results showed that green product positively affect empathy $(\mathrm{b}=1.00, \mathrm{SE}=.31, \mathrm{t}=3.23, \mathrm{p}=.001)$, where the respondents in green product condition were more concerned environmentally than those who were in the non-green product condition. However, there was no significant difference between the two groups in influencing purchase intention $(b=-$ $.02, \mathrm{SE}=.25, \mathrm{t}=-.07, \mathrm{p}=.94)$. In other words, the direct effect of green product on purchasing intention was not significant.
The effect of environmental concern on purchase intention was positive and significant $(\mathrm{b}=.16, \mathrm{SE}=.06, \mathrm{t}=2.66, \mathrm{p}<$ $.001)$. That is, the higher the environmental concern, the willingness to purchase green product is higher. As predicted, the indirect effect of green product on purchasing intention through environmental concern was significant $(\mathrm{b}=.16, \mathrm{SE}=$ $.09,95 \% \mathrm{CI}=.02, .37)$.

\section{DISCUSSION}

The result of this study confirms the mediating impact of environmental concern in the relationship between green product $(1=$ Yes, $0=$ No) and purchasing intention. This is important because prior studies in the area mostly were conducted in developed countries where the environmental concern is common among consumers [19]. This study provides a theoretical explanation of the link between green product and purchasing intention, especially when the study was conducted in a developing country.

Green marketing in developing countries is urgently needed, especially these days when excessive production of solid waste is increasing [19]. This study provides an empirical evidence of how to campaign a green product in a developing country. Therefore, this study presents a practical contribution to green marketing in general.

Despite its both theoretical and practical contributions, this study has several limitations. First, this study was conducted in a particular country (i.e., Indonesia), while consumers in developing countries may represent various characteristics. It would be useful to conduct a future study where the respondents come from different continents (e.g., South Asia, Africa, South America). Second, it is plausible that the research model could not be applied in all given conditions. Therefore, future studies may investigate moderating factors that alter the relationship between green product and purchasing intentions.

\section{CONCLUSION}

This study has discussed green marketing campaign, particularly in the context of developing country. It is expected that more research is conducted in this area due to the growing of environmental concern among consumers in developing countries. Future studies investigate how consumers in developed and developing countries may differ in responding to green marketing campaign.

\section{REFERENCES}

[1] C.-H. Tsen, G. Phang, H. Hasan, and M.R. Buncha, "Going green: A study of consumers' willingness to pay for green products in Kota Kinabalu," International Journal of Business Society, vol. 7, no. 2, pp. 40-54, 2006

[2] W. E. Kilbourne, "Green marketing: A theoretical perspective," Journal of Marketing Management, vol. 14, no. 6, pp. 641-655, 1998

[3] N.A.M. Noor et al., "Creating green consumers: how environmental knowledge and environmental attitude lead to green purchase behaviour?," International Journal of Arts Sciences, vol. 5, no. 1, p. 55, 2012 
[4] J. Angelovska, S.B. Sotiroska, and N. Angelovska, "The impact of environmental concern and awareness on consumer behaviour," Journal of International Environmental Application Science, vol. 7, no. 2, pp. 406-416, 2012.

[5] A. Balawera, "Green Marketing dan Corporate Social Responsibility Pengaruhnya Terhadap Keputusan Pembelian Konsumen Melalui Minat Membeli Produk Organik di Freshmart Kota Manado," Jurnal Riset Ekonomi, Manajemen, Bisnis dan Akuntansi, vol. 1, no. 4, 2013.

[6] V. Jauhari and K. Manaktola, "Exploring consumer attitude and behaviour towards green practices in the lodging industry in India," International Journal of Contemporary Hospitality Management, 2007.

[7] T.B. Chen and L.T. Chai, "Attitude towards the environment and green products: Consumers' perspective," Management science and engineering, vol. 4, no. 2, pp. 27-39, 2010.

[8] S. Szabo and J. Webster, "Perceived Greenwashing: The Effects of Green Marketing on Environmental and Product Perceptions," Journal of Business Ethics, pp. 1-21, 2020

[9] V. Albino, A. Balice, and R.M. Dangelico, "Environmental strategies and green product development: an overview on sustainability-driven companies," Business strategy the environment, vol. 18, no. 2, pp. 8396, 2009.

[10] R. Kasali, Membidik pasar Indonesia: segmenting, targeting, positioning. Jakarta: Gramedia, 1998.

[11] P. Shamdasani, G.O. Chon-Lin, and D. Richmond, "Exploring green consumers in an oriental culture: Role of personal and marketing mix factors," ACR North American Advances, 1993.

[12] A.S. Rini, I.P.G. Sukaatmadja, and I.G.A.K. Giantari, "Pengaruh Pengetahuan Lingkungan dan Kepedulian Lingkungan terhadap Sikap dan Niat Beli Produk Hijau "The Body Shop" Di Kota Denpasar," EJurnal Ekonomi dan Bisnis Universitas Udayana, 2017.
[13] S. H. Schwartz, "Universals in the content and structure of values: Theoretical advances and empirical tests in 20 countries," Advances in experimental social psychology, vol. 25, no. 1, pp. 1-65, 1992.

[14] S.S.H. Shah, "The impact of brands on consumer purchase intentions," Asian Journal of Business Management, vol. 4, no. 2, pp. 105-110, 2012.

[15] H. Simamora, Manajemen sumber daya manusia. Yogyakarta: STIE YKPN, 2004

[16] B. Martin and A. Simintiras, "The impact of green product lines on the environment," Journal of Marketing Intelligence \& Planning, 1995.

[17] G. Bohlen, B.B. Schlegelmilch, and A. Diamantopoulos, "Measuring ecological concern: A multi-construct perspective," Journal of marketing management, vol. 9, no. 4, pp. 415-430, 1993.

[18] A. Diamantopoulos, B.B. Schlegelmilch, R.R. Sinkovics, and G.M. Bohlen, "Can socio-demographics still play a role in profiling green consumers? A review of the evidence and an empirical investigation," Journal of Business research, vol. 56, no. 6, pp. 465-480, 2003.

[19] T. Ramayah, J.W.C. Lee, and O. Mohamad, "Green product purchase intention: Some insights from a developing country," Resources, Conservation and Recycling, vol. 54, no. 12, pp. 1419-1427, 2010.

[20] J. Pradeep, "Effect of environmental concern \& social norms on environmental friendly behavioral intentions," Business Intelligence Journal, vol. 5, no. 1, pp. 169-175, 2012.

[21] H.Y. Kim and J. E. Chung, "Consumer purchase intention for organic personal care products," Journal of consumer Marketing, 2011.

[22] A.F. Hayes, Introduction to mediation, moderation, and conditional process analysis: A regression-based approach. Guilford publications, 2017.

[23] A. Field, Discovering statistics using IBM SPSS statistics. sage, 2013. 